\section{Discoversys \\ Published by DiscoverSys \\ Women's Perception, Familial and Mass Media Influence upon Ratus Vaginal Douche Usage in Bali, 2013}

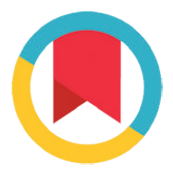

CrossMark

Widyastuti, ${ }^{1,4^{*}}$ Nazrina Zuryani, ${ }^{2}$ I Nyoman Mangku Karmaya ${ }^{1,3}$

\section{ABSTRACT}

Background and purpose: The ratus vaginal douching technique is a treatment by evaporation in the genital area, that compound is called "ratus". There are a number of controversies surrounding the ratus technique, especially regarding the benefits and detrimental aspects. This study applies a behaviour model Green (2007) with a focus on three factors: the determinant, supporting and stimulant. This study was aimed to understand the relationship perception, socio economic, familial, and mass media upon ratus vaginal douching usage.

Methods: This study used a quantitative approach with an analytic observational cross-sectional design. Study used random sampling of 63 samples that taken from 3 different Spas.
Results: The respondents were 44 (69.8\%) who performed the ratus vaginal douching and 19 (30.2\%) who had not performed. Results indicated that the variables of perception, knowledge, familial, and the mass media showed a significant correlation with the value of $(p<0.05)$. The result of multivariate analysis came from mass media that had the greatest influence with $0 R=8.47(95 \% \mathrm{Cl}$ : 1.21-59.42).

Conclusion: Mass media had the greatest influence on the use of the ratus vaginal douching in Bali Province.

Keywords: ratus vaginal douching usage, women`s perception, familial, mass media Cite This Article: Widyastuti, Zuryani, N., Karmaya, I.N.M. 2014. Women's Perception, Familial and Mass Media Influence upon Ratus Vaginal Douche Usage in Bali, 2013. Public Health and Preventive Medicine Archive 2(1): 12-16. D01:10.15562/phpma.v2i1.116

\title{
Persepsi Perempuan, Dukungan Keluarga dan Media Massa Berpengaruh pada Penggunaan Gurah Vagina Ratus, Bali, 2013
}

\section{ABSTRAK}

Latar belakang dan tujuan: Gurah vagina teknik ratus adalah perawatan dengan penguapan pada area genital yang ramuannya disebut dengan ratus. Ada beberapa kontroversi seputar teknik ratus, terutama mengenai manfaat dan aspek yang merugikan. Penelitian ini mengacu teori perilaku dari Green (2007) dengan fokus tiga faktor: penentu, pendukung dan pendorong, serta bertujuan untuk mengetahui hubungan antara persepsi, sosial ekonomi, dukungan keluarga dan media massa dalam penggunaan gurah vagina teknik ratus.

PPublic Health Postgraduate Program, Udayana University, ${ }^{2}$ Department of Sociology, Faculty of Social and Politics, Udayana University, ${ }^{3}$ Department of Anatomy, Faculty of Medicine Udayana University, ${ }^{4}$ Nur Tradisional Salon and Spa

*Correspondence to: Widyastuti, Public Health Postgraduate Program, Udayana University, Nur Tradisional Salon and Spa memoir_ti2@ymail.com
Metode: Penelitian ini menggunakan pendekatan kuantitatif dengan rancangan observasi potong lintang analitik. Studi menggunakan

\section{PENDAHULUAN}

Perkembangan teknologi membawa dampak pada tuntutan perubahan gaya hidup. Pusat sampel secara acak sebesar 63 orang yang merupakan klien diambil dari tiga tempat spa yang berbeda.

Hasil: Sebanyak 44 responden (69,8\%) melakukan gurah vagina teknik ratus dan 19 responden $(30,2 \%)$ tidak melakukan gurah vagina teknik ratus. Hasil penelitian menunjukkan variabel persepsi, pengetahuan, dukungan keluarga dan media massa mempunyai hubungan yang signifikan $(p<0,05)$. Analisis multivariat menunjukkan bahwa media massa memiliki pengaruh terbesar dengan $0 \mathrm{R}=8,47$ (95\% Cl: 1,21-59,42). Simpulan: Media massa memiliki pengaruh paling besar terhadap penggunaan gurah vagina ratus di Bali.

Kata kunci: penggunaan gurah vagina teknik ratus, persepsi perempuan, dukungan keluarga, media massa

Kutip artikel ini: Widyastuti, Zuryani, N., Karmaya, I.N.M. 2014. Persepsi Perempuan, Dukungan Keluarga dan Media Massa Berpengaruh pada Penggunaan Gurah Vagina Ratus, Bali, 2013. Public Health and Preventive Medicine Archive 2(1): 12-16. D0l:10.15562/phpma.v2i1.116

layanan yang berhubungan dengan perawatan tubuh baik perawatan medis maupun non-medis 
(termasuk menggunakan ramuan herbal) banyak bermunculan. Perawatan tubuh yang sering dikenal oleh masyarakat yaitu Sehat Pakai Air (SPA) yang mencakup perawatan tubuh, rambut dan kaki, baik bagi laki-laki ataupun perempuan.

Untuk konsumen perempuan, kini berkembang spa vagina yang dikenal dengan gurah vagina. Gurah vagina merupakan perawatan organ kewanitaan dengan menggunakan ramuan yang diuapkan disebut ratus yang terdiri dari tumbuhan herbal, rempah dan akar tumbuhan. ${ }^{1}$ Perawatan gurah vagina dengan ratus juga disertai perawatan dari dalam dengan mengkonsumsi jamu-jamuan. Tradisi ini berawal dari kebiasaan putri keraton, khususnya selir Kerajaan Surakarta terutama bagi wanita yang sudah menikah. ${ }^{1}$

Seorang androlog menyatakan bahwa kaum perempuan dengan gencar melakukan segala cara untuk mendapatkan kondisi vagina kering dan rapat layaknya masih perawan dengan melakukan perawatan gurah vagina yang banyak ditawarkan di pasaran. ${ }^{2,3}$ Ada berbagai versi gurah vagina selain dengan ratus, sebagai contoh adalah penggunaan produk tongkat gurah vagina (TGV), yaitu tongkat berbahan dasar Clerodendron serratum (daun senggugu) dan tujuannya untuk mengeluarkan lendir kotor yang tidak bermanfaat dari vagina. ${ }^{4}$

Faktor yang mendorong pengambilan keputusan dalam melakukan perawatan gurah vagina, salah satunya terkait dengan perilaku dari konsumen sebagai pemakai jasa. Berdasarkan kerangka konsep yang diadaptasi dari teori Lawrence Green (2007) mengenai perubahan perilaku, terdapat tiga faktor yang menentukan pengambilan keputusan yaitu faktor penentu, pendukung dan pendorong. ${ }^{5}$ Oleh sebab itu penting dilakukan penelitian lebih mendalam mengenai persepsi, pengetahuan, tingkat pendidikan, status ekonomi, fasilitas pendukung, sikap terapis, media massa dan dukungan keluarga dengan pilihan perawatan gurah vagina. Penelitian ini juga bertujuan untuk melihat apakah gurah vagina sebagai hal yang rutin dilakukan, faktor tradisi yang ada atau memang karena terbukti bermanfaat sesuai dengan mitos yang berkembang di masyarakat.

Penelitian Grimley (2006) mengenaikarakteristik perempuan yang melakukan pencucian vagina menemukan bahwa sebagian besar dengan tingkat pendidikan tidak tamat SMU (28,5\%), 17,6\% lulus SMU, 13,0\% tanpa gelar kesarjanaan, 3,7\% dengan gelar kesarjanaan (S1) atau lebih tinggi dan 37,2\% lain-lain. ${ }^{6}$ Martens dan Monif (2003) juga menyatakan bahwa perempuan dari ras kulit hitam, pendidikan rendah, pendapatan rendah dan memiliki riwayat penyakit menular seksual, yang melakukan douching cenderung menderita BV (bacterial vaginosis) sebesar $76,5 \%$ dibandingkan dengan yang tidak melakukan douching sebesar $19,1 \%$. $^{7}$

Hasil penelitian McKee (2009) menyatakan bahwa vaginal douching secara luas dipraktekkan oleh perempuan Amerika dengan status ekonomi yang rendah. ${ }^{8}$ Grimley menyatakan bahwa alasan utama wanita melakukan douching adalah merasakan bersih setelah menstruasi $(66,5 \%)$, mendapatkan kebersihan menyeluruh (43,6\%), membersihkan diri sebelum dan sesudah berhubungan seks (36,7\%), mengurangi bau vagina (26,9\%), mempunyai pendapat bahwa douching baik dan normal untuk dilakukan (19,4\%), karena mengeluarkan cairan abnormal (6,4\%), karena perdarahan menstruasi $(4,3 \%)$ dan untuk mencegah kehamilan $(3,0 \%){ }^{8}$

Berdasarkan hasil-hasil penelitian tersebut, penelitian ini bertujuan untuk mendalami hubungan persepsi, kondisi sosial ekonomi, dukungan keluarga dan pengaruh media massa dengan layanan gurah vagina teknik ratus di Nur Traditional Beauty Salon dan SPA, Keraton SPA dan Trendz Salon dan SPA pada Bulan Maret-Mei tahun 2013.

\section{METODE}

Metode yang digunakan dalam penelitian ini adalah pendekatan kuantitatif dengan rancangan analitik cross sectional. Pengumpulan data dilaksanakan dari Bulan Maret-Mei 2013. Populasi penelitian adalah perempuan yang datang di tiga tempat perawatan yaitu: Nur Traditional Beauty Salon dan SPA, Keraton SPA, dan Trendz Salon dan SPA. Sampel dipilih secara simple random sampling, sebanyak 63 orang berdasarkan rumus Slovin. ${ }^{9}$ Variabel bebas adalah persepsi, pengetahuan, tingkat pendidikan, status ekonomi, fasilitas pendukung, sikap terapis, dukungan keluarga dan pengaruh media massa. Sebagai variabel terikat adalah layanan gurah vagina teknik ratus. Pengumpulan data dilakukan dengan menggunakan kuesioner yang telah diuji validitas dan reliabilitasnya.

Variabel persepsi dikategorikan menjadi dua, yaitu positif apabila memiliki rentang skor 6-11 dan negatif memiliki rentang skor 1-5 dari 11 item pertanyaan. Pengetahuan dikategorikan menjadi dua, yaitu baik apabila memiliki rentang skor 5-20 dan kurang memiliki rentang skor 1-4 dari 20 item pertanyaan. Tingkat pendidikan dikategorikan menjadi dua, yaitu tinggi $\geq$ Diploma III dan menengah $<$ Diploma III. Status ekonomi dikategorikan menjadi dua yaitu tinggi apabila pendapatan $\geq 3$ juta/bulan dan menengah apabila pendapatan $<3$ juta/bulan. Fasilitas pendukung dikategorikan menjadi dua, yaitu baik apabila memiliki rentang skor 3-6 dan kurang memiliki 
rentang skor 1-2 dari 6 item pertanyaan. Sikap terapis diukur dengan tujuh pertanyaan memakai Skala Likert, yang dikategorikan menjadi dua, yaitu positif apabila memiliki rentang skor 16-28 dan negatif memiliki rentang skor 1-12 dari 7 item pertanyaan. Dukungan keluarga dikategorikan menjadi dua, yaitu tinggi apabila 4-7 dan rendah jika memiliki rentang skor 1-3 dari 7 item pertanyaan. Pengaruh media massa dikategorikan menjadi dua, yaitu sering apabila memiliki rentang skor 3-6 dan jarang memiliki rentang skor 1-2 dari 6 item pertanyaan.

Analisis dilakukan secara univariat untuk melihat distribusi frekuensi masing-masing variabel, bivariat untuk melihat hubungan dari masing-masing variabel bebas terhadap variabel terikat secara terpisah, sedangkan multivariat untuk mengetahui hubungan variabel bebas dengan variabel terikat secara bersama-sama. Penelitian telah dinyatakan laik etik oleh Komisi Etik Penelitian
Fakultas Kedokteran Universitas Udayana/Rumah Sakit Umum Pusat Sanglah Denpasar.

\section{HASIL}

Jumlah sampel dalam penelitian ini sebanyak 63 orang. Hasil analisa univariat menemukan bahwa sebagian besar responden 40 (63,5\%) mempunyai persepsi positif, $39(61,9 \%)$ pengetahuannya baik, $40(63,5 \%)$ tingkat pendidikannya tinggi, $36(57,1 \%)$ status ekonominya tinggi, 37 (58,7\%) fasilitas pendukungnya baik, 35 (55,6\%) sikap terapisnya positif, $37(58,7 \%)$ dukungan keluarganya tinggi dan 48 (76,2\%) sering terpapar media massa. Berdasarkan hasil analisis bivariat dengan menggunakan chi-squared test (Tabel 1) ditemukan hubungan signifikan antara layanan gurah vagina teknik ratus dengan: persepsi $(\mathrm{p}=0,004)$, pengetahuan $(\mathrm{p}=0,033)$, dukungan keluarga $(\mathrm{p}=0,020)$, dan media massa $(\mathrm{p}=0,025)$.

\section{Tabel 1 Crude OR persepsi perempuan, dukungan keluarga, media massa berpengaruh pada penggunaan gurah vagina ratus Bali 2013}

\begin{tabular}{|c|c|c|c|c|c|}
\hline \multirow[b]{2}{*}{ Variabel } & \multicolumn{2}{|c|}{ Gurah Vagina } & \multirow[b]{2}{*}{ Crude OR } & \multirow[b]{2}{*}{$95 \% \mathrm{Cl}$} & \multirow[b]{2}{*}{ Nilai $p$} \\
\hline & Ya & Tidak & & & \\
\hline \multicolumn{6}{|l|}{ Persepsi } \\
\hline Positif & $33(82,5 \%)$ & $7(17,5 \%)$ & 5,14 & $1,62-16,33$ & 0,004 \\
\hline Negatif & $11(47,8 \%)$ & $12(52,2 \%)$ & & & \\
\hline \multicolumn{6}{|l|}{ Pengetahuan } \\
\hline Baik & $31(79,5 \%)$ & $8(20,5 \%)$ & 3,28 & $1,07-10,02$ & 0,033 \\
\hline Kurang & $13(54,2 \%)$ & $11(45,8 \%)$ & & & \\
\hline \multicolumn{6}{|c|}{ Tingkat pendidikan } \\
\hline Tinggi & $25(62,5 \%)$ & $15(37,5 \%)$ & 0,35 & $0,10-1,23$ & 0,094 \\
\hline Menengah & $19(82,6 \%)$ & $4(17,4 \%)$ & & & \\
\hline \multicolumn{6}{|c|}{ Status ekonomi } \\
\hline Tinggi & $25(69,4 \%)$ & $11(30,6 \%)$ & 0,96 & $0,32-2,84$ & 0,937 \\
\hline Menengah & $19(70,4 \%)$ & $8(29,6 \%)$ & & & \\
\hline \multicolumn{6}{|c|}{ Fasilitas pendukung } \\
\hline Baik & $29(78,45 \%)$ & $8(21,6 \%)$ & 2,66 & $0,88-8,02$ & 0,078 \\
\hline Kurang & $15(57,7 \%)$ & $11(42,3 \%)$ & & & \\
\hline \multicolumn{6}{|l|}{ Media massa } \\
\hline Sering & $37(77,1 \%)$ & $11(22,9 \%)$ & 3,84 & $1,14-12,99$ & 0,025 \\
\hline Jarang & $7(46,7 \%)$ & $8(53,3 \%)$ & & & \\
\hline \multicolumn{6}{|l|}{ Sikap terapis } \\
\hline Positif & $27(77,1 \%)$ & $8(22,9 \%)$ & 2,18 & $0,73-6,52$ & 0,158 \\
\hline Negatif & $17(60,7 \%)$ & $11(39,3 \%)$ & & & \\
\hline \multicolumn{6}{|c|}{ Dukungan keluarga } \\
\hline Tinggi & $30(81,1 \%)$ & $7(18,9 \%)$ & 3,67 & $1,19-11,34$ & 0,020 \\
\hline Rendah & $14(53,8 \%)$ & $12(46,2 \%)$ & & & \\
\hline
\end{tabular}


Tabel 2 Adjusted OR persepsi perempuan, dukungan keluarga, media massa berpengaruh pada penggunaan gurah vagina ratus, Bali 2013

\begin{tabular}{lcccc}
\hline & & \multicolumn{2}{c}{$\mathbf{9 5 \% C l}$} & \multirow{2}{*}{ Nilai p } \\
\cline { 3 - 4 } Variabel & Adjusted OR & Lower & Upper & 0,012 \\
Persepsi & 8,11 & 1,60 & 41,19 & 0,036 \\
Pengetahuan & 5,27 & 1,11 & 24,98 & 0,882 \\
Tingkat pendidikan & 1,15 & 0,18 & 7,35 & 0,143 \\
Status ekonomi & 3,72 & 0,64 & 21,54 & 0,382 \\
Fasilitas pendukung & 2,10 & 0,40 & 11,01 & 0,032 \\
Media massa & 8,47 & 1,21 & 59,42 & 0,133 \\
Sikap terapis & 4,31 & 0,64 & 29,07 & 0,040 \\
Dukungan keluarga & 6,83 & 1,09 & 42,88 & \\
\hline
\end{tabular}

Berdasarkan hasil analisis multivariat (Tabel 2) menunjukkan bahwa terdapat empat variabel yang mempunyai hubungan signifikan secara bersama dengan layanan gurah vagina teknik ratus, yaitu variabel persepsi dengan $\mathrm{OR}=5,14$ (95\%CI: 1,62$16,33)$, pengetahuan dengan $\mathrm{OR}=3,28 \quad(95 \% \mathrm{CI}$ : 1,07-10,02), dukungan keluarga dengan $\mathrm{OR}=3,67$ (95\%CI: $1,19-11,34)$ dan media massa dengan $\mathrm{OR}=3,84 \quad(95 \% \mathrm{CI}: 1,14-12,99)$. Berdasarkan hasil dari analisa multivariat ditemukan bahwa variabel pengaruh media massa mempunyai kontribusi tertinggi.

\section{DISKUSI}

Hasil penelitian menunjukkan bahwa persepsi mempunyai hubungan signifikan dengan keputusan menggunakan layanan gurah vagina teknik ratus dengan OR=8,11 (95\%CI: 1,60-41,19). Persepsi merupakan suatu proses yang diawali oleh rangsangan yang diterima dari luar, diorganisasikan dan diinterpretasikan sehingga menimbulkan suatu pemahaman..$^{10}$ Hasil ini sesuai dengan penelitian McKee, yang menyatakan bahwa keyakinan, sikap dan norma sosial yang terkait dengan douching telah dilakukan oleh perempuan Amerika dan Afrika serta sesuai juga dengan hasil penelitian Hilber, yang menyatakan bahwa motif melakukan douching adalah mengurangi lendir sehingga memberikan sensasi rapat saat berhubungan seksual. ${ }^{8,11}$ Banyak pendapat yang salah tentang vaginal douching, yaitu anggapan bahwa tubuh akan kebal dari infeksi menular seksual yang disebabkan oleh human papilloma virus. ${ }^{12}$

Variabel pengetahuan menunjukkan bahwa ada hubungan signifikan antara pengetahuan dan keputusan menggunakan layanan gurah vagina teknik ratus. Pengetahuan merupakan hasil mencari tahu seseorang terhadap objek tertentu dan menjadi domain yang sangat penting dalam membentuk tindakan seseorang. ${ }^{13}$ Hasil ini sesuai dengan penelitian McKee, yang menyatakan bahwa sebagian besar perempuan yang melakukan douching mempunyai pemahaman bahwa douching, berhubungan dengan perasaan bersih setelah berhubungan seksual, setelah menstruasi dan ingin mencegah infeksi. ${ }^{8}$ Berdasarkan teori Green, perilaku yang didasari oleh pengetahuan akan lebih langgeng dibandingkan perilaku yang tidak didasari oleh pengetahuan. ${ }^{12}$ Hasil yang diperoleh tidak sesuai dengan teori Green, bahwa responden dengan pengetahuan baik bukan berarti tidak mengambil layanan gurah vagina teknik ratus, namun karena pengaruh gaya hidup maka responden tetap mengambil keputusan untuk melakukan gurah vagina teknik ratus.

Variabel tingkat pendidikan tidak mempunyai hubungan signifikan dengan gurah vagina teknik ratus dengan OR=1,15 (95\%CI: 0,18-7,35). Hasil ini tidak sesuai dengan penelitian Martens dan Monif bahwa perempuan dari ras kulit hitam dengan pendidikan rendah sering melakukan douching. ${ }^{7}$ Variabel status ekonomi tidak mempunyai hubungan signifikan dengan gurah vagina teknik ratus dengan $\mathrm{OR}=3,72$ (95\%CI: 0,64-21,54). Hasil penelitian ini tidak sesuai dengan penelitian McKee bahwa vaginal douching secara luas dipraktekkan oleh perempuan Amerika dan lebih umum di kalangan perempuan minoritas dan status ekonomi rendah. Hasil penelitian Gama juga menemukan bahwa vaginal douching banyak dilakukan oleh responden dengan status ekonomi rendah seperti pekerja seks komersial., ${ }^{8,14}$ Dilihat dari distribusi frekuensi, responden dengan status ekonomi tinggi lebih banyak mengambil layanan gurah vagina teknik ratus. Hal ini kemungkinan berkaitan dengan kemampuan membeli jasa perawatan tubuh secara umum.

Variabel fasilitas pendukung tidak mempunyai hubungan signifikan dengan layanan gurah vagina teknik ratus dengan OR=2,10 (95\%CI: 0,40 $11,01)$. Hasil ini tidak sesuai dengan teori yang 
menyatakan bahwa fasilitas pendukung termasuk dalam service quality seperti kelengkapan alat dan lingkungan fisik akan mempengaruhi pengambilan keputusan konsumen. ${ }^{15}$ Hasil penelitian ini menunjukkan bahwa sebagian besar konsumen tidak memanfaatkan fasilitas pendukung secara maksimal.

Variabel sikap terapis tidak mempunyai hubungan signifikan dengan layanan gurah vagina teknik ratus dengan $\mathrm{OR}=4,31 \quad$ (95\%CI: 0,64 29,07). Berdasarkan hasil penelitian, ditemukan bahwa sikap terapis tidak berhubungan dengan pengambilan keputusan. Sikap akan terwujud di dalam suatu tindakan tergantung pada situasi saat itu. ${ }^{13}$ Penelitian ini menemukan bahwa variabel dukungan keluarga mempunyai hubungan signifikan dengan keputusan memakai layanan gurah vagina teknik ratus dengan $\mathrm{OR}=6,83$ (95\%CI: 1,09-42,88). Hal ini sesuai dengan penelitian yang dilakukan oleh McKee bahwa responden biasanya mengetahui tentang douching dari anggota keluarga dan teman perempuan. ${ }^{8}$

Variabel media massa memberikan kontribusi tertinggi terhadap pengambilan keputusan memakai layanan gurah vagina teknik ratus dengan $\mathrm{OR}=8,47$ (95\%CI: 1,21-59,42). Hasil ini sesuai dengan penelitian Hilber bahwa di Indonesia, para wanita menggunakan produk herbal atau jamu yang dibuat khusus untuk mengencangkan vagina yang disebut dengan nama generik jamu sari rapat. ${ }^{11}$ Demikian pula dengan penelitian Hendarin di Kabupaten Tegal bahwa variabel iklan kesehatan seksual wanita berhubungan kuat dengan praktik bilas vulvo-vaginal. ${ }^{16}$

Media massa berfungsi sebagai alat bantu dalam memperlancar komunikasi dan penyebarluasan informasi yang dapat dilihat dan didengar. ${ }^{16}$ Informasi mengenai gurah vagina teknik ratus telah banyak beredar di masyarakat luas yang dapat diakses melalui situs internet maupun brosur yang disebarkan dan menu yang disediakan di berbagai tempat perawatan tubuh. Salah satu contoh adalah produk untuk organ kewanitaan yang direkomendasikan oleh Boyke Dian Nugraha, yaitu Tissue Majakani yang dapat melindungi, membersihkan dan mengencangkan organ intim kewanitaan. $^{18}$

\section{SIMPULAN}

Variabel yang terbukti berhubungan secara signifikan dengan layanan gurah vagina teknik ratus adalah persepsi, pengetahuan, dukungan keluarga, dan media massa. Variabel yang tidak terbukti berhubungan dengan layanan gurah vagina teknik ratus adalah tingkat pendidikan, status ekonomi, fasilitas pendukung, dan sikap terapis.

\section{UCAPAN TERIMA KASIH}

Ucapan terima kasih penulis sampaikan kepada pihak pengelola spa yang telah memberikan ijin penelitian serta semua pihak yang membantu terselesainya penelitian ini.

\section{DAFTAR PUSTAKA}

1. Murtie A. Ramuan herbal esensial. Cahaya Atma Pustaka; Yogyakarta. 2012.

2. Puspayanti. Mitos perbedaan seks pria dan wanita [cited 2013 February 3]. Available from URL: http:// threspuspa.wordpress.com/2012/02/29/mitosperbedaan-seks-pria-wanita

3. Dharmacita. Vagina kering dalam mitos seks. [cited 2012 December 12]. Available from URL: http://dhammacitta. org/forum/index.php/topic,2311.0.html

4. Detik.com. Tongkat gurah vagina. [cited 2012 October 10]. Available from URL: http://forum.detik.com/tongkatgurah-vagina-tgv-t380003.html

5. Notoatmodjo S. Promosi kesehatan dan ilmu perilaku. Rineka Cipta. Jakarta. 2010

6. Grimley DM, Anang L, Foushee HR, Bruce FC, Kendrick JS. Vaginal douches and other feminine hygiene products: women's practices and perceptions of product safety. Journal of Maternal and Child Health 2006. Vol. 10. No.3; 303-310.

7. Martens M and Monif GRG. Douching: a risk to women's healthcare. Jurnal Obstetrics and Gynecology 2003. Vol.11; 135-137.

8. McKee MD, Baquero $\mathrm{M}$, Anderson $\mathrm{MR}$, Alvarez $\mathrm{A}$, Karasz A. Vaginal douching among latinas: practices and meaning. Journal of Matern Child Health 2009. Vol.13; 98-106.

9. Sevilla CG. Research method. Quezon. 2007.

10. Walgito B. Pengantar psikologi umum. Andi Offset. Yogyakarta. 2010.

11. Hilber AM, Hull TH, Whyte EP, Bagnol B, Smit J, Wacharasin C, Widyantoro N. A Cross cultural study of vaginal practices and sexuality: implications for sexual health. Journal Social Science and Medicine 2010. Vol. 70; 392-400.

12. Farida A. Faktor risiko kondiloma akuminata pada pekerja seks komersial. Program Magister Epidemiologi Universitas Diponegoro. Semarang. 2006.

13. Notoatmodjo S. Promosi kesehatan dan ilmu perilaku. Rineka Cipta. Jakarta. 2007.

14. Gama A, Kusumawati Y, Aprilianingrum F. Pengaruh aktivitas seksual dan vaginal douching terhadap timbulnya infeksi menular seksual kondiloma akuminata pada pekerja seks komersial resosialisasi Argorejo Kota Semarang. Jurnal Penelitian Sains dan Teknologi 2008. Vol. 9. No. 1; 30-51.

15. Setiadi NJ. Perilaku konsumen. Kencana. Jakarta. 2010.

16. Hendarin ED. Faktor-faktor yang berpengaruh terhadap praktek bilas vulvo-vaginal pada pekerja seks komersial di Lokalisasi Peleman Kabupaten Tegal. Semarang. Program Magister Ilmu Kesehatan Masyarakat Universitas Diponegoro. 2009.

17. Mubarak WI. Promosi kesehatan untuk kebidanan. Salemba Medika. Jakarta. 2012.

18. Blogspot.com. Tissue Majakani. [cited 2013 June 17]. Available from URL: http://tissuemanjakani. blogspot.com

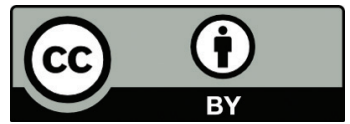

This work is licensed under a Creative Commons Attribution 